\title{
An Analysis Of Big Five Behavior Model Factors On Computer Self-Efficacy Teachers
}

\author{
Nurleila Jum'ati ${ }^{1}$ and Tri Siwi Agustina ${ }^{2}$ \\ \{nurleila@uwp.ac.id\} \\ Universitas Wijaya Putra, Surabaya, Indonesia ${ }^{1}$, Universitas Airlangga, Surabaya, Indonesia ${ }^{2}$
}

\begin{abstract}
This study aims to analyze the influence of the big five behavior models factors (extraversion, agreeableness, conscientiousness, neurotisicm, openness to experience) on teachers' computer self-efficacy in private senior high school and vocational school in Surabaya. The benefits of this study are expected to be used as guidelines for the schools and stake holders in managing and developing teachers. The population in this study were 52 teachers in private senior high school and vocational school in Surabaya using census methods, and 46 questionnaires were analyzed. Teacher computer self-efficacy data in this study was obtained from the CSE questionnaire, while the Big Five Behavioral Model data was obtained from Big Five Inventory (BFI) score, which analyzed quantitatively by multiple regression techniques with SPSS version 20.00. The result is, partially, the big five behavior models factors for dimension of agreeableness, conscientiousness, and openness to experience that influence CSE on teachers, while extraversion dan neurotisicm dimension does not influence significantly to CSE of private high schools and vocational teachers in Surabaya. Simultaneous, the Big Five Behavioral Model factor is significantly influence to CSE on private senior high schools and vocational school teachers in Surabaya. And the Big Five Behavioral Model extraversion dimension is dominant variable that influence CSE on private senior high school and vocational school teachers in Surabaya.
\end{abstract}

Keywords: Teacher, Computer Self-Efficacy, The Big Five Personality Factors.

\section{Introduction}

Reality in the field, in 2012 the teacher competency exam (UKG) was conducted in several regions in Indonesia by online. The results were conveyed by the Director of Middle Educators and Education Personnel (P2TK) of the Ministry of Education and Culture Surya Dharma (http://www.antarajatim.com/), the average participants were only able to answer 50 percent of all questions, and even participants could answer one question only. However, the initial facts or findings reflect the quality of the teaching staff if they finally get the certification stamp. Furthermore, the Minister of Education and Culture Mohammad Nuh (http://www.tempo.co/) said that the results of the Teacher Competency Test were far from its standard. From the assessment on three days of UKG implementation, the average value perched at 44.5. That value is still below the specified standard of 70 . 
Table 1. Teacher Competency Result (UKG) Tahun 2012.

\begin{tabular}{ll}
\hline Area & Precentage \\
\hline Yogyakarta & $48,92 \%$ \\
DKI Jakarta & $48,72 \%$ \\
Bali & $47,28 \%$ \\
Jatim & $46,18 \%$ \\
\hline
\end{tabular}

With problems in table 1 , belief in ability of individuals to computers when doing activities with computers (Computer Self Efficacy/CSE) both hardware, software and the internet. As educators, teachers are required to use computers. So that the attitude aspects of teachers in using computers are important factors that contribute to the expertise of computer users. It is understandable that CSE is important, but because of individual differences, not all individuals have such views. There are also those who have concerns about computers and information technology. Thus, the personality factors / behavioral tendencies that exist in the world of work educators are the Big Five (Luthans, 2006). The big five or five factor model (FFM) consists of: extraversion, agreeableness, conscientiousness, neuroticicm, openness to experience between one teacher and another teacher will be the basis of individual having a good CSE.

On the other hand, the Surabaya City Education Service has carried out an education information system through the internet. In the education information system (Perda No 16/2012) there is an information service that presents educational data including educational institutions, curricula, students, educators and education, facilities and infrastructure, financing, and government policies, local government and community participation that can be accessed by various parties who need it. With the education information system carried out by the Ministry of Education and Culture, it will impact on the increasing level of teacher welfare, increasingly clear promotion levels and more transparent supervision.

Based on the description above, further research is needed for the variables that influence computer self-efficacy, especially for high school-vocational school teachers, which can later be used as a benchmark for the development of subsequent policies, especially in human resource education and training for teachers in Indonesia. The aim of the study was to analyze the influence partially and jointly and significantly the big five behavioral factors on computer self-efficacy in high school and vocational school teachers in Surabaya.

\section{Literature Study}

\subsection{Definition of Computer Self-Efficacy (CSE)}

According to Brown (2008) CSE is defined as judgment of the capability of individuals to use computers / information systems / information technology. Based on social cognitive theory developed by Luthans (2010), self efficacy can be defined as the belief of individuals who could perform certain behaviors. Luthans (2010) further states that self-efficacy perceived by individuals plays an important role in influencing motivation and behavior. This is not a judgment on the past of individuals in using computers, but it concerns judgment that will be carried out in the future. 


\subsection{Dimensi Computer Self-Efficacy (CSE)}

Brown (2008) also explained that there are three dimensions of CSE, namely: (1) magnitude (2) strength and (3) generability. The magnitude dimension refers to the level of capability expected in computer use. Individuals who have high CSE magtitude are expected to be able to complete more complex computing tasks compared to individuals who have low levels of magtitude CSE due to lack of support or assistance. This dimension also explains, that high magtitude of individual CSEs is associated with the level needed to understand a task. Individuals who have a high level of magtitude CSE are able to complete their tasks with low support and support from others, compared to low levels of magtitude CSE.

In the second dimension, namely strength, this refers to the level of belief about judgment or the belief of an individual to be able to complete his computational tasks properly. The final dimension is generazability, which refers to the level of user judgment that is limited to the specific domain of activity. In the context of computers, this domain reflects differences in hardware and software configurations, so individuals who have a high level of CSE generazability are expected to be able to competently use different software packages and computer systems. In contrast, the low level of CSE generazability shows the ability of individuals to access software packages and computer systems in a limited way.

Agarwal (2000) divides CSE into two types, namely general CSE and specific CSE. These two types are constructed related to differences in computer tasks. In general, CSE is defined as judgment of individual expertise in using various computer applications. Whereas the specific CSE is the ability to create computer-related tasks specifically in the general computing domain.

The components of the CSE reflect the confidence of the individual's ability to acquire the necessary knowledge, skills and abilities related to the use of:

a. Computer hardware, which consists of hardware from a computer, among others: flash disk/external hard disk, mouse, key board, CPU / laptop / net book and others.

b. Computer software, which consists of software used to run programs to complete tasks such as using software packages for data analysis, writing mail merge letters using a word processor, spread sheet and others that more than simple skills such as formatting flash-disks or computer reboots.

c. Computer internet-related skills, the ability to use internet networks.

\subsection{Big Five Behavior Model}

The five main personality traits predict the interactions and performance of individuals in the workplace. According to the Fretzer Institute big five is the tendency of individual behavior in the form of a continuum, namely: extraversion vs. introversion, agreeableness vs. Antagonism, conscientiousness vs. lack of direction, neuroticism vs. neurotisicm, openness vs. closedness to experience. Further explained by Yuwono (2005) that the big five dimension includes:

a. Extraversion - introversion: a dimension that includes the level of individual pleasure in interacting. Extravenous individuals tend to be groupy, assertive, and able to socialize. Conversely, individuals tend to be quiet, shy and calm.

b. Agreeableness $\urcorner$ - antagonism: dimensions include the tendency of individuals to agree with other individuals. Individuals who can agree are characterized as cooperative, warm, and easy to trust other individuals. Conversely the antagonistic individual is a cold person and not easily affected.

c. Conscientiousness - lack of direction: dimensions that show individuals who have responsible, organized, trustworthy, and persistent personality traits. Conversely, individu- 
als who are characterized as individuals who are easily confused, unorganized and unreliable.

d. Neuroticism - emotional stability: a dimension that shows an individual's resistance to stress / stress. Individuals with high emotional stability tend to be calm, confident, and safe. Conversely, individuals who are neuroticism tend to be nervous, anxious, depressed, and feel threatened.

e. Openness - closedness to experience: a dimension that shows individual interest in new things. Individuals who are open to new things are individuals who are creative, curious and artistically sensitive. Conversely individuals who are less able to accept new things tend to be conventional and feel comfortable in familiarity.

The five dimensions above play an important role in determining suitability of the work demands with individual characteristics. Some of the roles of the big five personality dimensions according to Yuwono (2005) are as follows (a) conscientiousness: is the right predictor for achieving good performance in all types of work, and (b) extraversion can predict good performance in managerial positions and sales and other jobs that require social interaction.

Relationship between Big Five Behavior Model Factors (conscientiousness, agreeableness, conscientiousness, neuroticicm, openness to experience) with Computer Self Efficacy

Computer self efficacy that is owned by individuals with one another will vary. The diversity of CSE is partly due to the personality factors of the big five behavioral models that are owned by each individual, namely: extraversion, agreeableness, conscientiousness, neurotisicm, openness to experience.

Conceptual Framework

This study will examine 1 (one) independent variable, namely the big five behavior model factors. The dependent variable of this study is computer self-efficacy (CSE).

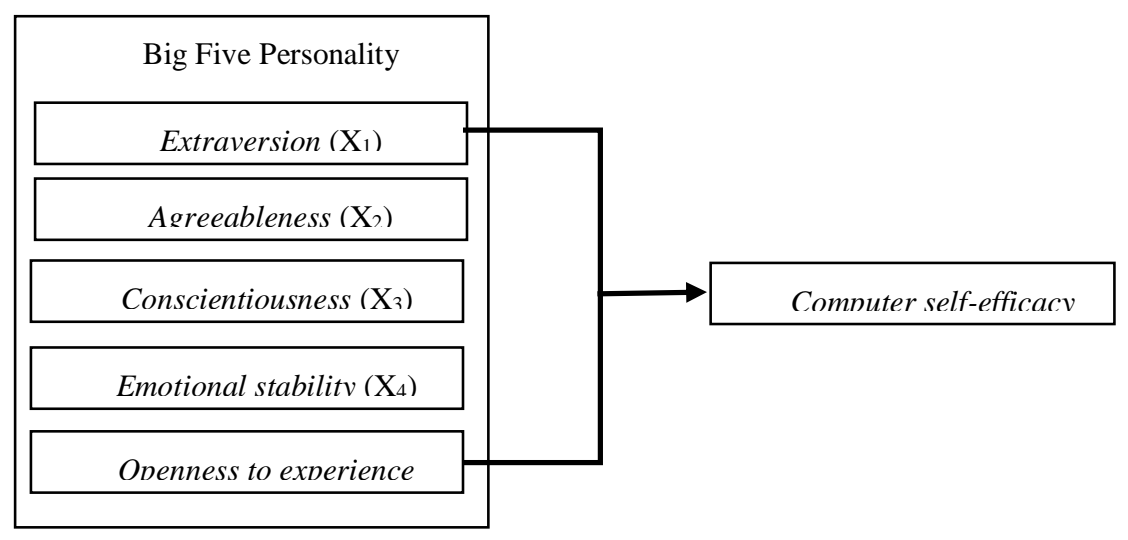

Hypothesis

Figure 1. Conceptual framework

Based on the theoretical framework and conceptual framework above, the research hypothesis can be formulated as follows:

1. There is a partial and significant influence of big five behavioral factors on computer selfefficacy and job satisfaction in high school and vocational high school teachers in Surabaya. 
2. There is a joint and significant influence between big five behavioral factors on computer self-efficacy and job satisfaction in high school and vocational high school teachers in Surabaya.

\section{Method}

The model used in this study is a model of causality or relationship of influence and reciprocity. To test the hypothesis proposed in this study, the analysis technique used is: multiple regression analysis between independent variables, namely the big five behavioral model factors and dependent variables: computer self efficacy. Processed data are primary data collected from questionnaires arranged based on indicators in variables using questionnaires with Likert scale 1 to 5 .

Population according to Sugiyono (2008) is a generalization area consisting of objects / subjects that have certain qualities and characteristics set by researchers to be studied and then conclusions drawn. The population of this study were 52 high school and vocational teachers. Further explained by Sugiyono (2008) that the sample is part of the population or part of the number and characteristics of the population, what is learned from the sample, the conclusion will be applied as a population, for that the sample must be representative / representative. With the census / saturation technique (Sugiyono, 2008), that is, all populations are used as research samples. The 52 questionnaires distributed which can be forwarded to the next process, which is processing data as many as 46 questionnaires.

The data analysis technique used in this study is linear multiple regression with the following formula (Riduwan, 2007):

$\mathrm{Y} 1=\mathrm{a}+\mathrm{b} 1 \mathrm{X} 1+\mathrm{b} 2 \mathrm{X} 2+\mathrm{b} 3 \mathrm{X} 3+\mathrm{b} 4 \mathrm{X} 4+\mathrm{b} 5 \mathrm{X} 5+\mathrm{e} \quad(1)$

Multiple linear regression tests are conducted to test the effect of independent variables on the dependent variable, namely factors $(\mathrm{X})$ to $(\mathrm{Y})$. Data analysis calculations in this study used manual statistical analysis and data processing with SPSS 20.

\section{RESULTS AND DISCUSSION}

Research result

Test Validity and Reliability

Validity test

Data collection used in this study using a questionnaire, then the questionnaire prepared must be measured for its validity. Linkage validity of statement items in one variable. To test the validity and failure of the statement to be submitted by comparing the value of $\mathrm{r}$ count compared to $\mathrm{r}$ table.

- Item is valid if $r$ count $>r$ table $(0.3)$

- Item is invalid if $r$ count $<\mathrm{r}$ table $(0,3)$

It is known that $r$ count of all computer variables self-efficacy between 0.363 and 0.835 and the behavior model of big five factors has a calculated $r$ value between 0.324 and 0.763 above $r$ table of 0.3 so that all items are in the questionnaire is valid.

Reliability Test 
Reliability is an index that shows the extent to which a measuring device can be trusted or reliable. If a measuring device is used twice or more to measure the same symptoms and the results are relatively consistent, the measuring device is reliable. In other words, the reliability shows consistency. The results of processing are obtained as follows:

Table 2. Reliability Test.

\begin{tabular}{llc}
\hline Variable & Cronbach's Alpha & Information \\
\hline Computer Self-Efficacy $(\mathrm{Y})$ & 0.976 & Reliabel \\
The Big Five Inventory $(\mathrm{X})$ & & \\
Conscientiousness $\left(\mathrm{X}_{1}\right)$ & 0.748 & Reliabel \\
Agreeableness $\left(\mathrm{X}_{2}\right)$ & 0,810 & Reliabel \\
Conscientiousness $\left(\mathrm{X}_{3}\right)$ & 0,792 & Reliabel \\
Neurotisicm $\left(\mathrm{X}_{4}\right)$ & 0,766 & Reliabel \\
openness to experience $\left(\mathrm{X}_{5}\right)$ & 0,825 & Reliabel \\
\hline
\end{tabular}

The measurement used is using Cronbach alpha, that is, if the Cronbach alpha is greater than 0.6 or $60 \%$, then the item statement is reliable. Based on the results of calculations, it is known that computer self-efficacy, and behavior models of big five factors are reliable, because they are greater than 0.6 or $60 \%$.

\section{Multiple Linear Regression Analysis}

Multiple regression analysis is used to determine how much influence the independent variables in this study have on the dependent variable. The value of the calculation for the influence between the big five behavioral model variables: extraversion (X1), agreeableness (X2), conscientiousness (X3), neurotisicm (X4), openness to experience (X5) on computer self-efficacy is as in the table the following:

Table 3. Regression Analysis of Coefficients

\begin{tabular}{|c|c|c|c|c|c|c|}
\hline \multirow{2}{*}{\multicolumn{2}{|c|}{ Model }} & \multicolumn{2}{|c|}{$\begin{array}{l}\text { Unstandardized Coeffi- } \\
\text { cients }\end{array}$} & \multirow{2}{*}{$\begin{array}{c}\begin{array}{c}\text { Standard- } \\
\text { ized Coeffi- } \\
\text { cients }\end{array} \\
\text { Beta }\end{array}$} & \multirow[t]{2}{*}{$\mathrm{t}$} & \multirow[t]{2}{*}{ Sig. } \\
\hline & & $B$ & Std. Error & & & \\
\hline \multirow{6}{*}{1} & (Constant) & 1,854 & ,697 & & 2,659 &, 011 \\
\hline & Extraversion &,- 007 & 141 &,- 008 &,- 050 & ,961 \\
\hline & Agreeableness & ,089 & ,138 & , 100 & ,643 &, 524 \\
\hline & Conscientiousness & ,438 & ,154 & ,448 & 2,840 & ,007 \\
\hline & Neuroticism & 101 &, 112 & ,125 & ,902 & ,373 \\
\hline & Openness &,- 001 & 141 &,- 002 &,- 010 & ,992 \\
\hline
\end{tabular}

a. Dependent Variable: COMPUTER SELF-EFFICACY

Based on the table 3 , the regression equation can be written as follows:

$\mathrm{Y}=1,854-0,007 \mathrm{X} 1+0,89 \mathrm{X} 2+0,438 \mathrm{X} 3+0,101 \mathrm{X} 4-0,001 \mathrm{X} 5+\mathrm{e}$ 
The results of the multiple regression equation above provide the understanding that:

a. The constitutional value of 1.854 shows that the value of computer self-efficacy of high school-vocational school teachers without any other variables or other variables is zero. Other variables are the big five behavioral model factors: extraversion (X1), agreeableness (X2), conscientiousness (X3), neurotisicm (X4), openness to experience (X5). So computer self efficacy is directly proportional to the constant value, if there is an increase in one unit on computer self efficacy then the constant value will also increase by 1,854 units.

b. For the factor variable of the big five behavioral model of the extraversion dimension (X1) the regression coefficient is negative and not significant, this can be interpreted that extraversion will not influence computer self-efficacy.

c. For the big five dimension of agreeableness (X2) behavioral model factor variable the regression coefficient is positive and not significant, this can be interpreted if individuals have easy tendency dimensions to have high agreement so it will not affect the computer selfefficacy.

d. For the big five behavioral model variable dimension five conscientiousness (X3) the regression coefficient is positive and significant, this can be interpreted as the higher the conscientiousness dimension possessed by the individual, the higher the computer self-efficacy. This means that with a high tendency toward conscientiousness, computer self-efficacy will also increase.

e. For the factor variable of the big five dimensions of neuroticicm (X4) behavior the regression coefficient is positive and not significant, it can be interpreted that the increasing the neurotic dimension of the individual does not affect the computer self-efficacy.

f. For the factor variable of the big five behavioral model of openness to experience (X5) the regression coefficient is negative and not significant, this can be interpreted if the openness to experience dimension is higher, it will not affect the computer self-efficacy.

Coefficient of Determination

The coefficient of determination $\left(\mathrm{R}^{2}\right)$ essentially measures how far the model's ability to explain the variation of the dependent variable. The coefficient of determination is between zero and one. A small $\mathrm{R}^{2}$ value means that the ability of independent variables to explain variations in the dependent variable is very limited. A value close to one means that the independent variables provide almost all the information needed to predict variations in the dependent variable.

Table 4. Koefisien determinasi Model Summary

\begin{tabular}{l|r|r|r|r|}
\hline Mod- & $R$ & R Square & $\begin{array}{l}\text { Adjusted R } \\
\text { Square }\end{array}$ & $\begin{array}{c}\text { Std. Error of the } \\
\text { Estimate }\end{array}$ \\
\hline 1 &, $519^{\mathrm{a}}$ &, 269 &, 178 &, 39980 \\
\hline
\end{tabular}

The coefficient of determination $\left(\mathrm{R}^{2}\right)$ essentially measures how far the model's ability to explain the variation of the dependent variable. The coefficient of determination is between zero and one. A small $\mathrm{R}^{2}$ value means that the ability of independent variables to explain variations in the dependent variable is very limited. A value close to one means that the independent variables provide almost all the information needed to predict variations in the dependent variable. 
Hypothesis testing

F Test

Based on the results of calculations with statistics with SPSS 20, the data values for the simultaneous influence of the big five behavioral model variables are obtained: extraversion, agreeableness, conscientiousness, neuroticicm, openness to experience with computer self efficacy in this study.

Table 5. ANOVA ${ }^{a}$

\begin{tabular}{|rl|r|r|r|r|r|}
\hline Model & Sum of Squares & df & Mean Square & F & Sig. \\
\hline \multirow{2}{*}{1} & Regression & 2,352 & 5 &, 470 & 2,943 &, $024^{\mathrm{b}}$ \\
& Residual & 6,394 & 40 &, 160 & & \\
& Total & 8,745 & 45 & & & \\
\hline
\end{tabular}

a. Dependent Variable: COMPUTER SELF-EFFICACY

b. Predictors: (Constant), Openness, Neuroticism, Agreeableness, Extraversion, Conscientiousness

Based on the table 5, it is known that $\mathrm{F}$ count $=2.943$, while using a significance level $\alpha=0.05$, the value of $\mathrm{F}$ table with df $1=5$ and $\mathrm{df} 2=40$ is obtained by $\mathrm{F}$ table of 2.45 . Then $\mathrm{F}$ count $>\mathrm{F}$ table, which is $2.943>2.45$. Thus, the big five behavioral model factors: extraversion, agreeableness, conscientiousness, neuroticicm, openness to experience have a simultaneous influence on computer self-efficacy of high school-vocational school teachers.

Based on table 5 also obtained a significance level of $0.024<0.05$, this indicates that the big five behavioral model factors: extraversion (X1.1), agreeableness (X1.2), conscientiousness (X1.3), neurotisicm (X1. 4), openness to experience (X1.5) together has an influence on computer self-efficacy (Y1). Thus the regression model in this study is good.

$\mathrm{t}$ test

$t$ test is used to determine whether each independent variable partially has a significant effect on the dependent variable. Can also be said if thitung>t table or -thitung <-ttabel, then the result is significant and means $\mathrm{Ho}$ is rejected and $\mathrm{Ha}$ is accepted. Whereas if tcount <ttable or -thitung > -ttable then the result is not significant and means $\mathrm{Ho}$ is accepted and $\mathrm{Ha}$ is rejected.

Based on table 5 for big five behavioral model factors: extraversion (X1), agreeableness (X2), conscientiousness (X3), neurotisicm (X4), openness to experience (X5) to computer self-efficacy (Y) the following results are obtained:

- $t$ test between the factors of the big five extraversion behavior model (X1) with computer selfefficacy $(\mathrm{Y})$ shows $\mathrm{t}$ count $=-0.50$ while the $\mathrm{t}$ table $(\mathrm{a}=0.05$; $\mathrm{df}$ residual $=40)$ is 2.021 . Because tcount $>$ $\mathrm{t}$ table is $0.50<2.021$ with a value of $\mathrm{p}=0.961$ (p50.05), the effect of the factor of the big five dimensions of extraversion (X1) on computer self-efficacy (Y) is not significant. This means that computer self-efficacy cannot be influenced by the big five behavioral model dimensions of extraversion.

- $t$ test between big five agreeableness behavior model (X2) and computer self-efficacy (Y) shows $t$ count $=0.643$ while $t$ table $(\mathrm{a}=0.05$; residual $\mathrm{df}=40)$ is 2.021 with $\mathrm{p}=0.524(\mathrm{p}>0.05)$. Because tcount $<t$ table is $0.643<2.021$, there is no effect of the big five agreeableness behavior model (X2) on computer self-efficacy (Y). This means that computer self-efficacy cannot be influenced significantly by the big five agreeableness behavior model factor.

- $t$ test between the behavioral factors of the big five conscientiousness (X3) and computer self-efficacy (Y) dimensions shows $\mathrm{t}$ count $=2.840$ while the $\mathrm{t}$ table $(\mathrm{a}=0.05$; residual $\mathrm{df}=40)$ is 2.021 with $\mathrm{p}$ values 
$=0.007(\mathrm{p}<0.05)$. Because tcount $>\mathrm{t}$ table is $2.840>2.021$ then there is the influence of the behavioral factor model of the big five dimensions of conscientiousness (X3) on computer self-efficacy (Y). This means that computer self-efficacy can be significantly influenced by the factors of the big five behavioral models of conscientiousness dimensions.

- $t$ test between the factors of the big five dimensional neuroticicm behavior model (X4) with computer self-efficacy $(\mathrm{Y})$ shows $\mathrm{t}$ count $=0.902$ while the $\mathrm{t}$ table $(\mathrm{a}=0.05$; residual $\mathrm{df}=40)$ is equal to 2.021 with $\mathrm{p}$ values $=0.373(\mathrm{p}>0.05)$. Because tcount $<\mathrm{t}$ table is $0.902<2.021$ then there is no effect of the factor of the big five dimensions neuroticicm behavior model (X4) on Computer self-efficacy (Y). This means that computer self-efficacy cannot be significantly influenced by the factors of the big five dimensions of neurotisicm behavior models.

- $t$ test between factors of the big five behavioral model of openness to experience (X5) and computer self-efficacy $(\mathrm{Y})$ shows $\mathrm{t}$ count $=-0.010$ while $\mathrm{t}$ table $(\mathrm{a}=0.05$; residual $\mathrm{df}=40)$ is 2.021 with $\mathrm{p}$ value $=$ $0.992(\mathrm{p}>0.05)$. Because tcount $<\mathrm{t}$ table is $-0.010<2.021$, there is no influence of the big five behavioral model dimensions of openness to experience (X5) on computer self-efficacy (Y). This means that computer self-efficacy cannot be significantly influenced by the big five behavioral model dimensions of openness to experience dimensions.

Dominant Variables

Based on table 5 for big five behavioral model factors: extraversion (X1), agreeableness (X2), conscientiousness (X3), neurotisicm (X4), openness to experience (X5) on computers self-efficacy (Y), it can also be known that the highest Standardized Coefficients Beta value is on the big five behavioral model variable conscientiousness dimension, so that the dominant variable influencing computer self-efficacy is the big five behavioral model model of conscientiousness dimensions.

Discussion

Effect of Big Five Behavior Model Factors: Extraversion, Agreeableness, Conscientiousness, Neurotisicm, Openness To Experience Against Computer Self-Efficacy

The summary of the research results of the big five dimension behavioral model factors: extraversion, agreeableness, conscientiousness, neuroticicm, openness to experience on computer self-efficacy indicate that:

1. In the big five behavioral factor model of extraversion dimensions, $\mathrm{t}$ count $=-0.50$ while $\mathrm{t}$ table $(\mathrm{a}=$ 0.05 ; $\mathrm{df}$ residual $=40$ ) is equal to 2.021 so there is no influence of big five extraversion behavior model on computer self-efficacy .

2. In the big five behavioral model of agreeableness dimension $t$ count $=0.643$ while $t$ table $(a=0.05$; $\mathrm{df}$ residual $=40$ ) is equal to 2.021 , there is no influence of the big five agreeableness behavior model factor on computer self-efficacy.

3. on the big five behavioral model factor, the dimension of conscientiousness $t$ count $=2.840$ while the $\mathrm{t}$ table $(\mathrm{a}=0.05$; df residual $=40)$ is equal to 2.021 , there is the influence of the big five behavioral model factors of conscientiousness on computer self-efficacy.

4. In the big five neuroticicm dimension model with $\mathrm{t}$ arithmetic $=0.902$ while $\mathrm{t}$ table $(\mathrm{a}=0.05$; df residual $=40$ ) is 2.021 , there is no influence of the big five dimension neuroticicm behavior model on Computer self-efficacy.

5. In the big five behavioral model factor the openness to experience dimension $t$ count $=-0.010$ while the $t$ table $(a=0.05$; $d$ residual $=40)$ is equal to 2.021 so there is no influence of the big five dimensions of openness to experience on computer self-efficacy.

It can be concluded that from the five factors of big five dimensional behavioral model: extraversion, agreeableness, conscientiousness, neuroticicm, openness to experience is only one dimension which has 
a partial effect on computer self-efficacy in Surabaya high school - vocational teachers namely conscientiousness. The results of the study reinforce the statement conveyed by Yuwono (2005) that of the five dimensions of the big personality five conscientiousness dimensions are the right predictors for achieving good performance in all types of work. With this statement, all types of work will require a conscientiousness personality dimension, including teachers in SMA - SMK on computer self-efficacy. Thus, teachers with conscientiousness personality dimensions will carry out routine tasks and responsibilities for teaching staff, especially teachers in secondary education in Surabaya. With good self-confidence in interacting with computers and the internet. This will improve the teacher's competence.

The results of this study are also partly consistent with the results of Hadjam and Widhiarso (2011) who stated that the five factors in the Big Five Personality concept, there are two factors that can support the teaching efficacy of teachers, namely resilient personality factors and openness. This shows that the higher the tenacity and openness of the teacher, the better the teacher's teaching performance through teaching efficacy mediators. The dimensions of conscientiousness or tenacity between the results of this study and the results of research conducted by Hadjam and Widhiarso (2011).

The difference in the results of this study and the results of Hadjam and Widhiarso's research (2011) are the dimensions of personality openness to experience, this is due to differences in the study sample. Hadjam and Widhiarso's research samples were outstanding teachers representing all provinces in Indonesia, totaling 142 people with 65 people (46\%) men and 77 people (54\%) women. Age of respondents ranged from 24 to 57 years with an average of 41.23 years.

The results of Hadjam and Widhiarso (2011) who convey the dimensions of openness to experience are supported by the results of Abdillah (2008) research which shows that only the openness to experience factor has a significant effect on the intention to use the internet. These results are in accordance with the findings of research conducted by Tuten and Bosnjak (in Abdillah, 2008) which show that people with characters who tend to look for new things will be motivated to engage in cyberspace activities to adventure and explore new ideas, characters who like art, high imagination and love to hear new ideas, are the driving force for users to use the internet.

\section{Conclusion}

1. Big five behavioral model factors dimensions: extraversion, agreeableness, conscientiousness, neuroticicm, openness to experience on Computer Self-Efficacy only on the big five behavioral model models of agreeableness, conscientiousness and openness to experience while dimensions: extraversion and neurotisicm have no effect significantly towards Computer Self-Efficacy at SMA - SMK Surabaya Teachers.

2. Big five behavioral model factors significantly influence Computer Self-Efficacy in Surabaya High School - Vocational Teachers.

3. The factor of the big five behavioral models of conscientiousness dimensions is the dominant variable affecting Computer Self-Efficacy in Surabaya High School - Vocational Teachers.

Suggestion

1. The limitations of this study namely not include in examining the influence of demographics, big five dimension behavioral model factors: extraversion, agreeableness, conscientiousness, neuroticicm, openness to experience and Computer Self-Efficacy on the performance of Surabaya High School Vocational Teachers, this is important because can be known what the impact of demographics on computer use on 
teacher performance, so it is expected that the next researcher to enter the performance variable in his research.

2. Conducting personality tests in recruiting and selecting teachers is not only based on education level

3. For the government to pay attention to benefits and careers for teachers.

\section{Reference}

[1] Abdillah, Willy., (2008). Pengaruh Kepribadian Disposisional terhadap Niat Penggunaan Internet: Studi Empiris Keberterimaan Teknologi Informasi pada Lingkungan Perguruan Tinggi. National Conference on Management Research 2008 ISBN: 979-442-242-8 Makassar, 27 November 2008

[2] Agarwal, Rithu, V. Sambamurthy and R.M. Stair, 2000, "Research Report: The Solving Relationship between General and Specific Computer Self Efficacy - An Empirical Assessment”, Information Systems Research, Vol. 11, No. 4.

[3] Hadjam, M. Noor Rochman., Widhiarso, Wahyu. (2011). Efikasi Mengajar Sebagai Mediator Peranan Faktorkepribadian Terhadap Performasi Mengajar Guru. Humanitas. Vol. VIII No. 1 Januari 2011

[4] Hidayah, Sofi Fitria. Prof. Dr. MMW. Tairas, MA.Procoun. 2013. Perbedaan Tingkat Teacher Efficacy ditinjau dari Status Sertifikasi pada Guru Sekolah Menengah Atas di Tuban. Fakultas Psikologi Universitas Airlangga Surabaya Jurnal Psikologi Pendidikan dan Perkembangan Vol. 2, No. 01, Februari 2013.

[5] http://www.antarajatim.com/ 27 Mei 2012

[6] http://www.tempo.co/ 5 Agustus 2012

[7] Luthans, Fred. 2012. Perilaku Organisasi, Edisi Kesepuluh. Andi. Yogyakarta.

[8] Peraturan Daerah Kota Surabaya Nomor 16 Tahun 2012 Tentang Penyelenggaraan Pendidikan

[9] Riduwan. Sunarto. 2014. Pengantar Statistika Untuk Penelitian : Pendidikan, Sosial, Komunikasi, Ekonomi, dan Bisnis. AlfaBeta.

[10] Sugiyono. 2015. Metodologi Penelitian Pendidikan : Pendekatan Kuantitatif, Kualitatif dan R\&D. Alfa Betha. Bandung.

[11] Umar, Husein., 2002. Metode Riset Bisnis., Jakarta: Penerbit PT Gramedia Pustaka Utama.

[12] Undang-Undang Republik Indonesia Nomor 20 Tahun 2003 Tentang Sistem Pendidikan Nasional

[13] Yuwono, Ino., Fendi Suhariadi., Seger Handoyo., Fajrianthi., Budi setiawan Muhammad, Berlian Gressy Septarini. 2005. Psikologi Industri dan Organisasi. Fakultas Psikologi Universitas Airlangga. 